\title{
OBITUAEY. \\ JOSEPH O'KELLY, M.A., M.R.I.A., ETC.
}

Joseph O'Kelly died at his residence, 72, Eccles Street, Dublin, on April 13th. He was born in Dublin in 1832, being the second son of Matthias Joseph O'Kelly, who was well known as an ardent supporter of Natural History when few thought anything about it; his private collection of shells being one of the best then in existence.

Joseph O'Kelly matriculated in Trinity College, Dublin, in 1852, from which he also obtained a Diploma in Engineering, and after spending a few years with Sir R. Griffith, Bart., engaged on the General Valuation of Ireland, he joined the Irish branch of H. M. Geological Survey, 1854, Sir H. de la Beche being Director-General, and Prof. J. Beete Jukes Local Director. In the publications of that service his name appears in many of the memoirs and maps ; his more important work being the examination of the Cork Rocks. He was subsequently selected by Jukes to risit with him and examine the rocks of Devonshire and Cornwall ; the Igneous Rocks of Limerick, and the Coal-fields of the Queen's County and Tipperary. The Tipperary Coal-field was examined most minutely, and he made some important discoveries therein, while his Memoir is very exhaustive and most trustworthy, and forms a lasting record of his energy and research. This work was carried out with his then colleagues, Messrs. A. B. Wynne and G. H. Kinahan, who were present while every bed in this great and important section was examined and neasured; furthermore, the continuous surface section, which was also carefully examined by Jukes, proves the accuracy of their under-ground work. It was during the progress of this work that O'Kelly contracted the ill-health he subsequently suffered from; on account of the exposure and hardships he had to endure, often living for weeks in houses very little better than sheds, into which the wind and rain freely entered. His last regular work in the field was in the Co. Galway, after which he was transferred to Dublin, on the retirement of Mr. John Kelly, to occupy the post of Secretary, which he held till the time of his death. On this account of late years his name does not often appear in the Survey publications, but at the same time his great knowledge of Irish geology was surpassed by few. His affability, honesty, and straightforwardness made him a favourite with all, and a dear and trusted friend of many. He was only in his 5lst year, and might reasonably have hoped to have lived longer, had not his constitution been impaired by his previous field-work, having since then been subject to attacks of acute bronchitis, one of which in the end suddenly carried him off. He had served 30 years as an officer of the Irish branch of the Geological Survey. 